\title{
WOMEN'S LETTERS TO WALT WHITMAN: SOME CORRECTIONS
}

\author{
Sherry Ceniza
}

IN November of 1887 Whitman received a letter from an admirer signed "A. H. Spaulding." Edwin Haviland Miller, in his "Calendar of Letters Written to Whitman," volume four of The Correspondence, annotates this letter: "From A. H. Spaulding (reporting his defense of WW's "Children of Adam" before a Boston literary society)." Two separate Spaulding listings appear in the index to this volume: "Spaulding, A. H., 431" and "Spaulding, Mrs. A. H., 155n, 303, 312, 437." The cumulative index-volume six-includes the two distinct Spaulding listings and adds the entries for volume five under "Spaulding, Mrs. A. H." 1

I want to draw attention to the pronoun "his" in Miller's annotation. The writer of the letter did not report "his defense" of "Children of Adam," because the A. H. Spaulding who wrote the November 3rd letter to Whitman is the same Spaulding who wrote the other letters cited as "Spaulding, Mrs. Ada H.," a woman who, in the five letters she wrote to Whitman, never identified herself as "Mrs." In four of the five, she used "A. H. Spaulding" as her closing; in one, "Ada H. Spaulding."

In each of her letters, she mentioned Whitman's poetry. In the November 3rd letter, Spaulding singled out "Children of Adam"; she spoke of writing a paper to defend "Children of Adam." It is especially important, in light of Whitman's sexual politics and contemporary reception of Whitman by those interested specifically in the degree of empowerment that Whitman's poetry provided and provides female readers, for readers of Whitman to know that it was a woman-not a man-publicly defending "Children of Adam" in that November 3rd letter. It is also significant to note that her defense took place in Boston five years after the Boston District Attorney banned distribution of the 1881-82 edition of Leaves of Grass unless objectionable poems and passages were removed, many of those passages coming from the "Children of Adam" cluster.

Spaulding's letter begins:

For years I have owed you a debt. I wouldn't say it in any other way-so I am trying to get others to take from you just as largely. I am writing a paper for one of our Boston 
Clubs and it is to be all about you or your Leaves of Grass. Of course it has all been better said, but I must have my chance just the same. I am defending your Children of Adam. ${ }^{2}$

Shortly after Spaulding presented this paper on "Children of Adam," Ernest Rhys spoke to the New England Women's Club. The March 6, 1888 issue of the Boston Evening Transcript, in a column called "The Listener," reviewed Rhys's lecture before the New England Women's Club on "The New Poetry" in which Rhys praised Whitman's presentation of "the whole far-stretched United States and the further sweep of space, international and interstellar, in the full light of the modern spirit." 3 In the discussion which followed-a discussion which "showed no little sympathy with the lecturer's ideas" - the "Listener" columnist singled out A. H. Spaulding's support of Whitman: "One lady, Mrs. Spaulding, spoke in eloquent praise of Whitman. . . ."

On other occasions, Spaulding was joined in her public support of Whitman in Boston by Elizabeth Porter Gould, who, in a May 17, 1888 letter to Whitman spoke of her and Spaulding's defense of Whitman at a meeting of the Home Club. At this meeting, Gould and Spaulding defended Leaves "against violent antagonism."

In March of the next year-1889-Spaulding visited Whitman, and at this time, Whitman inscribed a copy of Leaves of Grass for her. Deeply moved by her brief visit with him, she immediately wrote Whitman and offered reassuring words when she told him that "Sometime America will know what you have done for her." She struck another chord important to Whitman - his need to create "in men's and women's hearts, young and old, endless streams of living, pulsating love and friendship" - when she added "in the meantime, souls, here and there in sorrow and in gladness, think of you and love you." She closed her letter: "With deep gratitude, A. H. Spaulding." Whitman wrote on her calling card: "dear friend of $\mathrm{L}$ of $\mathrm{G} \&$ me-a middle-aged lady-I sh'd say-one of the real circle." 6

That April, Whitman spoke to Traubel of a letter he had received from Hamlin Garland in which Garland spoke of Spaulding: "I saw Mrs. Dr. Spaulding recently. She is doing all she can for the acceptance of Leaves of Grass." 7 The Curator of Rare Books at the Boston Public Library sent me the following information on Spaulding: "In a book by Elizabeth P. Gould was inserted the calling card of Dr. \& Mrs. E. F. Spaulding. The card is signed 'Ada H. S.' (husband-Ebenezer Farrington Spaulding who died in 1919)." In Garland's letter, the disparity again surfaces between the way that Spaulding identified herself in all of her correspondence-never as "Mrs.," never as "Mrs. Dr."-and the way she has been identified by male writers, telling us something about society's conception of women's role as the "other," a conception which Spaulding appears not to have shared. 
Whitman himself commented on the culture's gender-based conventions of social titling in a November 1889 talk he had with Traubel when he spoke of some photographs he was autographing for an admirer and regretted not knowing her first name. Traubel recounts the incident: "Had also laid aside pictures for Mrs. Lewis-transcribing these, also-but regretting he could not write her down 'Mary or What-not'Lewis instead of 'Mrs. Enoch Lewis' - not knowing her first name, nor do I."9 Several months later, Traubel shared with Whitman a letter he had received from a mutual friend, Elizabeth Fairchild (who had introduced Spaulding to Whitman): "That Mrs. Fairchild signed herself 'Elizabeth Fairchild' in the letter I [Traubel] received today seemed to awaken a curious line of reasoning in him. 'Is it some sudden new development of woman's-rights-ism?' he asked-some [?] of independence?" 10 Though Whitman did not consistently speak the concerns that radical activists for women's rights supported in his day, his acute sensitivity to the politics of gendered language and to the complexities of sexuality and its positioning power meant that his views and activist women's views frequently coincided.

Spaulding wrote Whitman again on January 4, 1890, and spoke to him of her public support. Interestingly, in light of the poet-persona in Leaves, she told Whitman that she had been speaking for him: "I have had the pleasure of talking for you, and of you again. Yes - and a deep interest was aroused. It was good to hear the listeners say-'I promise you-I will read him now." In an August 1891 letter she spoke to Whitman of his "brave true words," and in the last letter she wrote him, December 26, 1891-just a note really, speaking of his illness-she told Whitman that his words had made a difference: "There are many, now, who give thanks for your glorious work. ... Y You have helped make homes happy, you have taught lovers to love wisely, you have helped men to pray, who, but for you would have known only irreverence."

Why is it significant to know that the A. H. Spaulding who defended "Children of Adam" was female? For those of us who consider the issue of empowerment a vital one in textual study, knowing that female readers defended Leaves of Grass, and, specifically, "Children of Adam," discourages an ahistorical reading of Whitman's gender consciousness. Knowing about women like A. H. Spaulding (and there were others) requires us today to question our own frames of reference. It requires us to explore possibilities in Whitman's poetry that we might otherwise all too complacently overlook. Also, the A. H. Spaulding annotation signals a problem in scholarship which we are now in the process of addressing - that is, the problem created in our scholarship by our own misreading of gender.

Another entry in the "Calendar" has come to my attention in the course of my work excavating the stories of women whom Whitman 
knew and admired and who knew and admired him in turn. This entry appears in the volume two "Calendar" of The Correspondence: "April 8 [1872]. From Pedelia (?) Bates."11 The name of this correspondent is Redelia Bates, who at the time of this letter was actively involved in the National Woman Suffrage Association. Prior to this, in the June 10, 1869 classified section of the Revolution, Bates advertised her services as a Notary Public. At this time, she lived in St. Louis. Soon after the advertisement appeared, however, she moved to Brooklyn, and articles about and by her began appearing in Anthony and Stanton's Revolution. ${ }^{12}$ Knowing who Bates was, knowing the nature of her politics, and knowing that she sought Whitman out adds another name to the list of activist women familiar with Whitman's work. In the letter to Whitman, addressed from her Brooklyn home, Bates spoke of Whitman's and her "brief acquaintance in Washington." No doubt the occasion for her visit to Washington was the National Woman Suffrage convention. $^{13}$

Bates's letter does more than document women's rights activists' reception of Leaves, however. The letter is significant biographically in another aspect as well. The year 1872 is noteworthy for Whitman's outbursts of anger-most dramatically the anger and schism between him and William D. O'Connor. In 1872, he became more outspoken in his letters to Anne Gilchrist, dissuading her in her love for him; he had an outburst of anger toward Abby Price's daughter Helen over a ring of his that Helen had worn home; and he also reacted angrily towards Redelia Bates when she came to visit him in Brooklyn. Bates's response, a formally written note, sought to assure Whitman that her object in visiting him was

that of friendly interest which I had been encouraged to think was reciprocal during our brief acquaintance in Washington. If my presence was an intrusion pray pardon it, but do not I beseech you attribute to presumption or idle curiosity that which sprang only from the most disinterested feelings of friendship.

Trusting that this explanation will exonerate me from all undeserved suspicion, I have the honor to remain

Most respectfully Redelia Bates ${ }^{14}$

It is difficult to ascribe any one cause to Whitman's outbursts of anger in 1872 . We do know some of the effects, however. We know the traumatic effect of his anger on his friendship with O'Connor. We have Redelia Bates's letter in which she intimates that his anger towards her was unjustified. We have Abby Price's letter to Louisa Van Velsor Whitman speaking of his outburst of anger toward her daughter Helen and also intimating that Whitman overreacted-uncharacteristically. And we have Helen Price's words, in an 1895 letter to Maurice Bucke, 

untold:

[Y]et I have seen him under the influence of strong excitement, and once was the unhappy cause of making him very angry. I may tell you the story sometime, but only by word of mouth. ${ }^{15}$

Biographers could add texture to their account of this turbulent year in Whitman's life by including Price's and Bates's letters as part of Whitman's story.

\section{Texas Tech University}

\section{NOTES}

1 Walt Whitman, The Correspondence, ed. Edwin Haviland Miller (New York: New York University Press, 1961-1977), 4:431; 6:114. The Winter/Spring 1991 Walt Whitman Quarterly Review special issue on Whitman's correspondence reprints the Spaulding entries in "A Calendar of Letters" as they appear in The Correspondence.

2 The five letters I mention here from Spaulding to Whitman are in the Feinberg Collection, Library of Congress.

3 “The Listener," Boston Evening Transcript, March 6, 1888, 4.

4 Horace Traubel, With Walt Whitman in Camden (New York: Rowman and Littlefield, 1961), 1:169.

5 Walt Whitman, "Preface, 1876, to Centennial Edition," Prose Works 1892, ed. Floyd Stovall (New York: New York University Press, 1964), 2:471.

6 Feinberg Collection.

7 Horace Traubel, With Walt Whitman in Camden, ed. Sculley Bradley (Philadelphia: University of Pennsylvania Press, 1953), 4:491.

8 Roberta Zonghi, Letter to Sherry Ceniza, August 19, 1987.

9 Horace Traubel, With Walt Whitman in Camden, eds. Gertrude Traubel and William White (Carbondale: Southern Illinois University Press, 1982), 6:146.

10 Traubel, 6:226.

11 Another problem in deciphering handwriting occurs in the January 9, 1891 entry in the "Calendar," in volume five of The Correspondence and in the recent WWQR edition (Winter/Spring 1991). The January 9, 1891 date assigned to Henry Clapp's letter to Whitman should read January 9, 1871. Clapp died in 1875, and so although the date does indeed look like 1891, it has to be 1871 .

12 In a May 12, 1870 article in the Revolution on a recent National Woman Suffrage Convention, the reporter spoke of Bates: "Miss Anthony was followed by spirited remarks from Miss Redelia Bates, late of the West, now of Brooklyn." In the October 13, 1870 issue of the Revolution, a biographical sketch on Stanton by Bates appeared, "Elizabeth C. Stanton at Home."

13 In 1877, Redelia Bates married Albert Brisbane. 
14 Redelia Bates, Letter to Walt Whitman, April 8, 1872, Feinberg Collection.

15 Helen Price, Letter to Maurice Bucke, September 29, 1895, Feinberg Collection. 